\title{
Tracing carbon flow from microphytobenthos to major bacterial groups in an intertidal marine sediment by using an in situ ${ }^{13} \mathrm{C}$ pulse-chase method
}

\author{
Tetsuro Miyatake, ,1,a Tanja C. W. Moerdijk-Poortvliet, ${ }^{1}$ Lucas J. Stal, ${ }^{1,2}$ and \\ Henricus T. S. Boschker ${ }^{1, *}$ \\ ${ }^{1}$ Royal Netherlands Institute for Sea Research (NIOZ), Yerseke, The Netherlands \\ ${ }^{2}$ Department of Aquatic Microbiology, Institute for Biodiversity and Ecosystem Dynamics, University of Amsterdam, Amsterdam, \\ The Netherlands
}

\begin{abstract}
Carbon flow from benthic diatoms to heterotrophic bacterial was traced in an intertidal sediment for 5 consecutive days. ${ }^{13} \mathrm{C}$-labeled bicarbonate was sprayed onto the sediment surface during low tide and ${ }^{13} \mathrm{C}$-label incorporation in major carbon pools, intermediate metabolites, and biomarkers were monitored. Phospholipidderived fatty acid (PLFA) and ribosomal ribonucleic acid (rRNA) were used to identify the responsible members of the microbial community at class and family phylogenetic resolution. Diatoms were the predominant primary producers, and Gammaproteobacteria, Bacteroidetes, and Deltaproteobacteria $(21 \%, 8 \%$, and $7 \%$ of $16 \mathrm{~S}$ rRNAderived clone library) were major heterotrophic bacterial groups. Both ${ }^{13} \mathrm{C}-\mathrm{PLFA}$ and ${ }^{13} \mathrm{C}$-rRNA data suggest a fast transfer of label from diatoms $\left(60 \mathrm{nmol}{ }^{13} \mathrm{C} \mathrm{g}^{-1}\right.$ dry weight [dry wt] $)$ to bacteria $\left(7 \mathrm{nmol}{ }^{13} \mathrm{C} \mathrm{g}^{-1} \mathrm{dry}\right.$ wt) during the first $24 \mathrm{~h}$, which was probably due to the exudation of low-molecular-weight organic compounds by diatoms that could be directly utilized by bacteria. After this initial fast transfer, labeling of bacteria proceeded at a slower rate to $13 \mathrm{nmol}{ }^{13} \mathrm{C} \mathrm{g}^{-1} \mathrm{dry}$ wt on the third day of the experiment, which coincided with the degradation of carbohydrates in water-extractable extracellular polymeric substances (EPS) initially produced by the diatoms. Water-extractable EPS (primarily as glucose) was a major intermediate and its turnover explained $75 \%$ of the total carbohydrate processing in the sediment. Labeling in bacteria tracked labeling in the diatoms, suggesting a closely coupled system. The heterotrophic bacterial groups benefited equally from the organic matter released by the diatoms, suggesting limited specialization in this microbial food web.
\end{abstract}

Marine intertidal areas are highly productive ecosystems, and microphytobenthos contributes importantly to the total primary production of estuaries and other shallowwater coastal ecosystems (MacIntyre et al. 1996; Underwood and Kromkamp 1999). Benthic diatoms are typically the dominant microphytobenthos in marine intertidal sediments from temperate regions (Underwood and Paterson 2003), and they are known to exude large amounts of carbohydrates such as extracellular polymeric substances (EPS). Some, but not all, of the EPS is released as a consequence of the motility of the diatoms and their migration through the sediment. As a result of the EPS production, diatoms stabilize the sediment surface and avoid their re-suspension in the water column (Paterson and Black 1999). Hence, diatoms provide a major carbon source to the benthic food web, which includes heterotrophic bacteria in marine intertidal sediments (Smith and Underwood 1998; van Oevelen et al. 2006).

Diatoms exude different types of carbohydrates, which vary in structure and composition depending on the environmental conditions and the nutrient status (Smith and Underwood 2000; de Brouwer and Stal 2001). Lowmolecular-weight compounds released by diatoms can be

*Corresponding author: eric.boschker@nioz.nl

a Present address: Department of Microbial Ecophysiology, Faculty of Biology/Chemistry, University of Bremen, Bremen, Germany directly utilized by the heterotrophic microbial community (Sundh 1992), whereas high-molecular-weight compounds such as EPS first need to be hydrolyzed by extracellular enzymes produced by microorganisms (Fuchs et al. 1998; Hunter et al. 2006). The microbial community composition of intertidal sediments has been extensively studied (Rusch et al. 2003; Bühring et al. 2005; Hunter et al. 2006) as is the case for the EPS formation by benthic diatoms (Smith and Underwood 1998; Haynes et al. 2007). However, there are only a limited number of studies that link in situ carbon flow from diatoms directly to heterotrophic microbes and also identify in detail the responsible microorganisms (Taylor et al. 2013).

Middelburg et al. (2000) and Evrard et al. (2008) have reported rapid transfer of carbon from microphytobenthos to bacterial biomass by combining in situ ${ }^{13} \mathrm{C}$ pulse-chase labeling and phospholipid-derived fatty acid (PLFA) biomarker analysis in order to differentiate between labeling in algae and heterotrophic bacteria. Previous studies suggested that EPS-derived carbohydrates were major intermediates in the transfer of organic matter between benthic diatoms and heterotrophic bacteria (Bellinger et al. 2009; Oakes et al. 2010; Taylor et al. 2013). Although it is possible to estimate the biomass based on the abundance of distinctive PLFAs (Middelburg et al. 2000), the phylogenetic resolution of these biomarkers is limited and the bacteria utilizing the organic matter produced by the benthic diatoms cannot be identified to sufficient detail (Boschker and Middelburg 2002). In general, 16S ribosomal ribonucleic acid (rRNA) provides a much higher phylogenetic resolution than is possible with 
PLFA, and it is widely used to identify microbial communities in natural environments. MacGregor et al. (2002) developed a method where $16 \mathrm{~S}$ rRNA from defined phylogenetic groups was isolated by using specific oligonucleotide probes attached to paramagnetic beads for subsequent stable isotope analysis. Miyatake et al. (2009, 2013) further improved the stable isotope probing with magnetic bead capture hybridization (Mag-SIP) and demonstrated the utilization of organic substrates in marine sediments by certain microbial groups at the family level.

The in-situ ${ }^{13} \mathrm{C}$ pulse-chase method was used to trace the carbon flow in an intertidal benthic diatom mat for $5 \mathrm{~d}$. In situ stable-isotope labeling approaches have the advantage over laboratory-based incubations that environmental conditions such as waves, tidal currents, sediment mixing, and pore-water flow are not disturbed (Middelburg et al. 2000). However, the inevitable loss of label that occurs in an open system could complicate quantitative interpretation of the data. We used 16S rRNA (Mag-SIP) and PLFA biomarkers for the identification of the major active microbial groups involved in the carbon transfer and to quantify their ${ }^{13} \mathrm{C}$-label incorporation rates. Furthermore, we used liquid chromatography combined with isotope ratio mass spectrometry (LC-IRMS) to trace ${ }^{13} \mathrm{C}$ in intermediate metabolites such as the total carbohydrates in the sediment (bulk carbohydrates), water- and ethylenediamine-tetra-acetate (EDTA)-extractable carbohydrates, and short-chain organic acids (SCOA) including volatile fatty acids. Although other extraction schemes for carbohydrate exist (Underwood et al. 1995), we studied bulk carbohydrates as well as water- and EDTA-extractable carbohydrates, which are two fractions that are commonly used to characterize loosely and stronger bound extracellular carbohydrates, respectively, in benthic diatom mats (Underwood et al. 1995; de Brouwer and Stal 2001). A clone library derived from reverse-transcribed 16S rRNA was also constructed in order to determine the metabolically active microorganisms and relate this to the specific oligonucleotide probe set used in the Mag-SIP protocol.

In the present study, we followed the carbon flow through intermediates produced by the diatoms and identify water-extractable carbohydrates as a major intermediate. We also show that all members of the heterotrophic bacterial community that we took into account in our analyses appeared to be equally involved in the assimilation of organic matter produced by the diatoms, suggesting little specialization at the taxonomic level of this study.

\section{Methods}

Study site, in situ ${ }^{13}$ C labeling, and sampling-From 14 to 19 April 2009, an in situ ${ }^{13}$ C-labeling experiment was performed at an intertidal flat in the Zandkreek area $\left(51^{\circ} 33^{\prime} \mathrm{N}, 3^{\circ} 53^{\prime} \mathrm{E}\right)$ of the Oosterschelde bay (The Netherlands). The sampling site was located $0.15 \mathrm{~m}$ below the mean tidal level, and the exposed period was $\sim 6 \mathrm{~h}$ per tidal cycle (Fig. 1A). The sediment contained $6.8 \%$ silt $(<63 \mu \mathrm{m}$ particle size) and was covered by a diatom mat. Salinity and water temperature were $28.5^{\circ}$ and $15^{\circ} \mathrm{C}$, respectively, and were constant during the experimental period. The weather was mostly sunny with high light levels (photon irradiance up to $1500 \mu \mathrm{mol} \mathrm{m} \mathrm{m}^{-2} \mathrm{~s}^{-1}$; Fig. 1A) and an average mean air temperature of $16.2^{\circ} \mathrm{C}$. Almost no rainfall occurred during the experimental period except for some minor drizzle on the third day.

During the first day of the experiment, shortly after the exposure of the site at low tide, two $50 \times 50 \mathrm{~cm}$ stainless frames were inserted into the sediment to a depth of $8 \mathrm{~cm}$ in order to constrain the labeling and sampling area (the top rim of the frames was flush with the sediment surface). Initially, unlabeled control sediment and pore water $(n=2)$ were taken from just outside the frames as described below. The in situ labeling experiment was started by spraying the surface of the sediment within each frame with $250 \mathrm{~mL}$ of $\left[{ }^{13} \mathrm{C}\right]$ sodium bicarbonate $\left(99 \%{ }^{13} \mathrm{C}\right.$; Cambridge Isotope Laboratories). The label solution was at the ambient salinity and contained $1 \mathrm{~g} \mathrm{~L}^{-1}$ of $\left[{ }^{13} \mathrm{C}\right]$ sodium bicarbonate (equaled to $1 \mathrm{~g}$ [13 C] sodium bicarbonate $\mathrm{m}^{-2}$; Middelburg et al. 2000). The frames were divided in a $10 \times 10 \mathrm{~cm}$ sampling grid. The first sampling of the labeled sediment was performed after $4 \mathrm{~h}$ at the end of the same exposed period (the pulse-labeling period), and the two frames were sampled in a time-course of $12 \mathrm{~h}, 1 \mathrm{~d}, 2 \mathrm{~d}, 3 \mathrm{~d}$, and $5 \mathrm{~d}$ (the chase period).

The two frames were treated as duplicates $(n=2)$. At each sampling time, pore-water and sediment samples were collected and mixed from two randomly chosen positions within the sampling grid of each frame. Pore water (two times $1 \mathrm{~mL}$ ) was sampled with porous polymer sippers (Rhizon Soil Moisture Sampler; Eijkelkamp Agrisearch Equipment) inserted into the upper $1.5 \mathrm{~cm}$ of the sediment. For ${ }^{13} \mathrm{C}$-DIC (dissolved inorganic carbon) analysis, $1 \mathrm{~mL}$ of mixed pore-water sample per frame was dispensed into air-tight headspace vials. The remainder of the pore-water sample was used for ${ }^{13} \mathrm{C}-\mathrm{SCOA}$ analysis. Subsequently, sediment was sampled by inserting a corer (inside diameter $10 \mathrm{~cm}$ ) to a depth of $5 \mathrm{~cm}$, and the top $1.5 \mathrm{~cm}$ of the sediment was collected. The sampling hole was filled with unlabeled sediment collected just outside the sampling frames and the corer was removed. The two sediment samples taken from each frame were homogenized, and divided in the field into eight samples of 20-25 g wet weight (wet wt) each for Mag-SIP analysis; one sample of $45 \mathrm{~g}$ wet wt for the measurement of total organic carbon (TOC), PLFA, and bulk carbohydrates; and a sample of $5 \mathrm{~g}$ wet wt for pigment analysis. Additionally, $\sim 2 \mathrm{~g}$ wet wt of the homogenized sediment was directly processed for waterextractable carbohydrates by adding it to $4.5 \mathrm{~mL}$ Milli-Q water as described in de Brouwer and Stal (2001). The samples were immediately transferred on ice to the laboratory. In the laboratory, samples for water-extractable carbohydrates were shaken for $1 \mathrm{~h}$ at $30^{\circ} \mathrm{C}$ and the supernatant was collected after centrifugation at $4000 \times g$ for $15 \mathrm{~min}$ and stored for carbohydrate analysis. The sediment pellet was re-extracted with $4.5 \mathrm{~mL}$ of $0.1 \mathrm{~mol} \mathrm{~L}^{-1}$ EDTA by shaking for $4 \mathrm{~h}$ at room temperature. The supernatant was collected after centrifugation at $4000 \times g$ for $15 \mathrm{~min}$, and stored for EDTA-extractable carbohydrate analysis. Sediment samples for Mag-SIP and pigment analysis were stored at $-80^{\circ} \mathrm{C}$ while the other samples were stored at $-20^{\circ} \mathrm{C}$. 

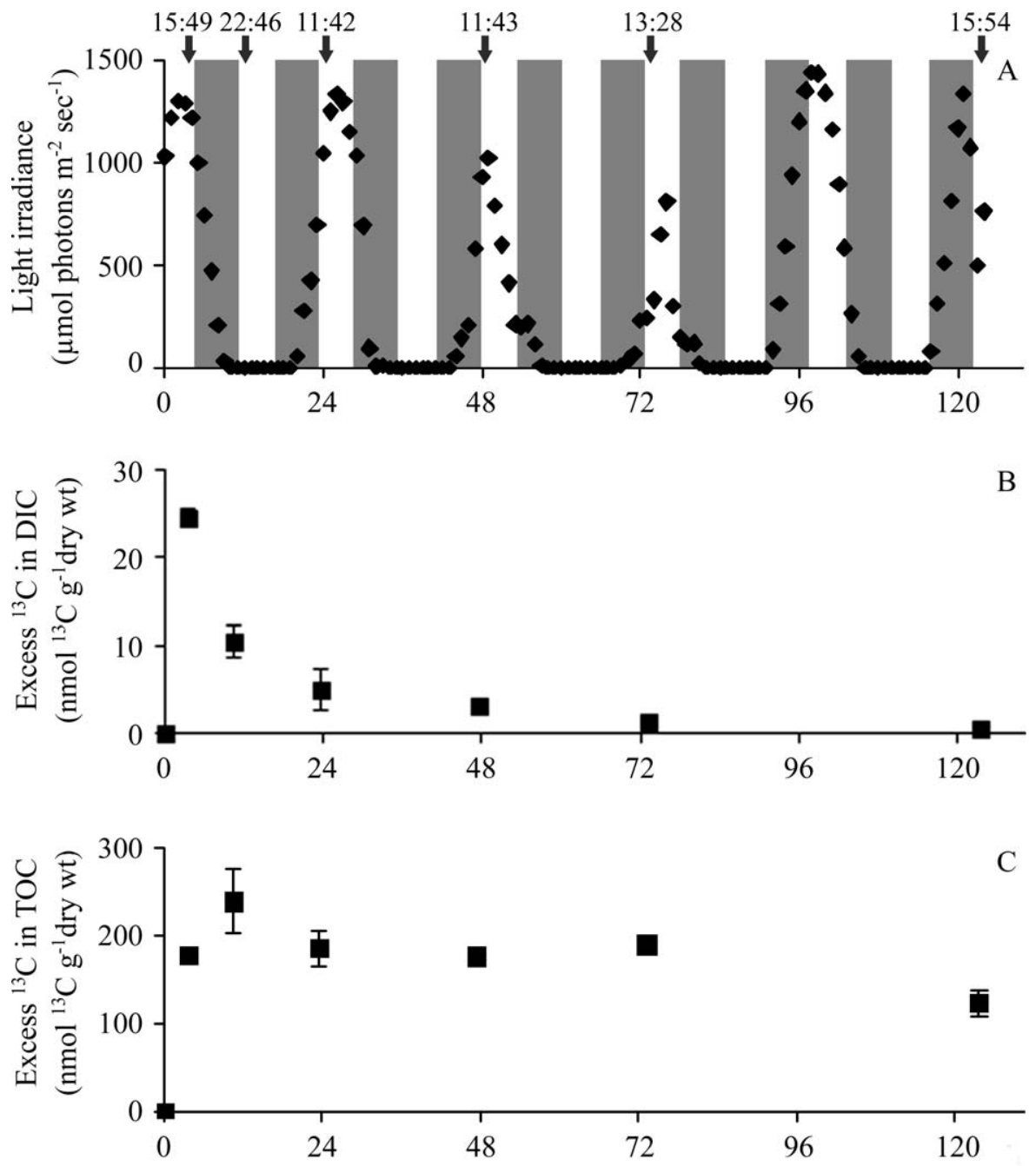

(h)

Fig. 1. (A) Light irradiance during the experiment period. Shaded part is indicating submerged period of the sampling site. Sampling times are indicated by arrows. Average values of excess ${ }^{13} \mathrm{C}$ in (B) DIC and (C) TOC are shown as a function of time $(n=2)$. Error bars show the range in the duplicate data.

To study dark fixation by chemoautotrophic and heterotrophic bacteria, two cores $(7 \mathrm{~cm}$ internal diameter) were taken outside the frames and incubated in the dark for $4 \mathrm{~h}$ with the same amount of ${ }^{13} \mathrm{C}$-label $\left(\right.$ per $\mathrm{m}^{2}$ ) added to the top of the sediment as in the field. The top $1.5 \mathrm{~cm}$ of these cores was sampled and analyzed for PLFA labeling.

Analytical procedures-Sediment samples for PLFA, TOC, pigment, and bulk carbohydrate analysis were freeze-dried. Lipids were extracted from $3 \mathrm{~g}$ of freeze-dried sediment using a modified Bligh and Dyer extraction (Boschker et al. 1999) from which the PLFA fraction was separated on a silica column. The PLFA fraction was converted to fatty-acid methyl esters and the carbon content and isotopic composition of these derivatives were measured by gas chromatography-combustion-isotope ratio mass spectrometry (Middelburg et al. 2000). The carbon content and isotopic composition of TOC was analyzed by using an elemental analyzer-isotope ratio mass spectrometer (EA-
IRMS) after the removal of carbonate with hydrochloric acid (Boschker et al. 1999). For DIC analysis, pore-water samples were acidified by adding $0.1 \mathrm{~mL}$ of $19 \mathrm{~mol} \mathrm{~L}^{-1}$ phosphoric acid (Miyajima et al. 1995), and headspace gas was injected into EA-IRMS in order to determine the concentration and isotopic composition of DIC. Pigments were extracted from freeze-dried sediment with acetone (90\%, buffered with 5\% ammonium acetate), and analyzed by reverse-phase high-performance liquid chromatography (HPLC; Dijkman and Kromkamp 2006).

Carbon content and isotopic composition of SCOA were analyzed by LC-IRMS (Isolink interface and DELTA V Advantage IRMS; Thermo Fisher Scientific) equipped with an Aminex HPX-87H cation-exchange column (Bio-Rad). The eluent was $8 \mathrm{mmol} \mathrm{L}^{-1}$ sulfuric acid at a flow rate of $0.4 \mathrm{~mL} \mathrm{~min}^{-1}$ (Krumbock and Conrad 1991).

The monosaccharide composition of bulk, water-extractable, and EDTA-extractable carbohydrates was determined by LC-IRMS (Boschker et al. 2008). Freeze-dried sediment 
and carbohydrate extracts were hydrolyzed with $1.1 \mathrm{~mol} \mathrm{~L}^{-1}$ sulfuric acid for $1 \mathrm{~h}$ at $120^{\circ} \mathrm{C}$. The hydrolyzed carbohydrates were neutralized with strontium carbonate, and the precipitate was removed by centrifugation. Carbohydrate concentrations and isotope ratios were measured by LCIRMS (see above) equipped with a Carbopac PA20 (Dionex Benelux). The eluent was $1 \mathrm{mmol} \mathrm{L}^{-1}$ sodium hydroxide at a flow rate of $0.3 \mathrm{~mL} \mathrm{~min}-1$.

Concentration or ${ }^{13} \mathrm{C}$-labeling of compounds above was expressed as mole of carbon per gram of dry weight sediment (C or ${ }^{13} \mathrm{C} \mathrm{g} \mathrm{g}^{-1}$ dry wt) in order to directly compare the size of each pool and to trace label transfer. Water content of the sediment was constant through the experiment at $0.32 \pm$ $0.02 \mathrm{~g}$ per gram of sediment wet weight.

Mag-SIP analysis and clone library construction-A nested set of oligonucleotide probes was used for the Mag-SIP protocol (Table 1; Miyatake et al. 2013). The probes EUB338 (Amann et al. 1990) and DELTA495a (Loy et al. 2002) were used for most Bacteria and Deltaproteobacteria, respectively, even though they do not target all genera in these domains. The DELTA495a probe was used in combination with a competitor probe, cDELTA495a (Macalady et al. 2006), to avoid capture of Gammaproteobacteria, which have only one different base in the target region of DELTA495a. The family Desulfobacteraceae was covered with the probe Dbact653 (Miyatake et al. 2009) and the probe BG553 was used for Gammaproteobacteria (Miyatake et al. 2013). Both the Dbact653 and BG553 probes were used in combination with unlabeled helper probes complementary to the consensus sequence upstream and downstream of the probe target in order to increase yield (Fuchs et al. 2000; MacGregor et al. 2002). The probe CYA361 (Schönhuber et al. 1999) was used for Cyanobacteria and chloroplasts.

Hybridization of $16 \mathrm{~S}$ rRNA with oligonucleotide probes and the isotope analysis of captured 16S rRNA were done as described in Miyatake et al. (2009). In short, total RNA was extracted from the sediment with the chloroformphenol method and 20-40 $\mu \mathrm{g}$ total RNA was hybridized with biotin-labeled probes. The $16 \mathrm{~S}$ rRNA-probe hybrids were captured with streptavidin-coated hydrophobic paramagnetic beads (Dynabeads MyOne Streptavidin T1; Invitrogen). Captured 16S rRNA was released from the beads by heat, and $\sim 500 \mathrm{ng}$ of this rRNA was used for stable isotope measurement by using flow injection analysis (FIA: Isolink interface with DELTA V Advantage IRMS; Thermo Fisher Scientific). Samples (in $50 \mu \mathrm{L}$ ) were directly injected into this FIA-IRMS operating in bulk injection mode. The carbon blank was also determined by performing the Mag-SIP protocol but without the RNA extract.

In order to identify active members of the microbial community and determine the specificity of the oligonucleotide probes used in the Mag-SIP protocol, clone libraries derived from total RNA and captured 16S rRNA were constructed. The total RNA extracted from the sediment with the chloroform-phenol method ( $0 \mathrm{~h}$ sample) and captured $16 \mathrm{~S}$ rRNA were reverse-transcribed with reverse primer DXR518 (Nogales et al. 1999). The reverse transcripts were amplified by polymerase chain reaction (PCR) using primers $27 \mathrm{~F}$ DXR518 (Mills et al. 2005; Martinez et al. 2006). The PCR products were ligated into pGEM T-easy vector (Promega) and transformed into Escherichia coli JM109 competent cells following the manufacturer's instructions. Positive clones were re-amplified with M13 primers, and sequenced with the 27F primer on an ABI PRISM 3130 Genetic Analyzer (Applied Biosystems). Sequence chromatographs were manually checked using the Chromas Lite software (http://www.technelysium.com.au/chromas_lite.html). Phylogenetic analysis was performed by using the fast aligner and treeing tools implemented in the ARB program package (Ludwig et al. 2004). Phylogenetic relationships were determined by inserting sequences from this study into an ARB tree composed of the Greengenes database (http://greengenes.lbl.gov/) to which additional Deltaproteobacteria clone sequences from marine environments had been added. Nucleotide sequences obtained in this study have been deposited in GenBank under accession numbers GU215079-GU215169.

Calculations of label incorporation-Stable carbon isotope ratios were expressed as $\delta^{13} \mathrm{C}$ values calibrated against the international standard Vienna Pee Dee Belemnite (VPDB). The delta notation is defined as

$$
\delta^{13} \mathrm{C}_{\text {sample }}(\%)=\left[\left(\mathrm{R}_{\text {sample }} / \mathrm{R}_{\text {st }}\right)-1\right] \times 1000
$$

where $R_{\text {sample }}$ is the ratio of ${ }^{13} \mathrm{C}$ in the sample and $R_{\text {st }}$ is the ratio of the international standard VPDB (0.0111797).

Captured rRNA was measured by bulk injection and therefore a correction for the blank was necessary. Correction of $\delta^{13} \mathrm{C}_{\mathrm{rRNA}}$ value for the blank is done as

$$
\begin{aligned}
& \delta^{13} \mathrm{C}_{\mathrm{rRNA}}(\%)= \\
& \quad\left[\frac{\left(\delta^{13} \mathrm{C}_{\text {sample }} \times \mathrm{C}_{\text {sample }}\right)-\left(\delta^{13} \mathrm{C}_{\text {blank }} \times \mathrm{C}_{\text {blank }}\right)}{\mathrm{C}_{\text {sample }}-\mathrm{C}_{\text {blank }}}\right]
\end{aligned}
$$

where $\mathrm{C}_{\text {sample }}$ is the amount of carbon in the sample, $\delta^{13} \mathrm{C}_{\text {blank }}$ is the $\delta^{13} \mathrm{C}$ value of the blank, and $\mathrm{C}_{\text {blank }}$ is the amount of carbon in the blank (Boschker 2004). ${ }^{13} \mathrm{C}$-label incorporation in rRNA is indicated as the increase of $\delta^{13} \mathrm{C}$ value between background (unlabeled sample) and labeled samples $\left(\Delta \delta^{13} \mathrm{C} ; \%\right)$.

The absolute amount of ${ }^{13} \mathrm{C}$ atoms incorporated into different carbon pools over the background was expressed as excess ${ }^{13} \mathrm{C}$ and calculated from $\delta^{13} \mathrm{C}_{\text {sample }}$ as

$$
\begin{aligned}
& \text { Excess }{ }^{13} \mathrm{C}\left(\mathrm{mol}^{13} \mathrm{C} \mathrm{g} \mathrm{g}^{-1} \text { dry wt }\right)= \\
& {\left[\left(\frac{\left(\delta^{13} \mathrm{C}_{\text {sample }} / 1000+1\right) \times \mathrm{R}_{\text {st }}}{\left(\delta^{13} \mathrm{C}_{\text {sample }} / 1000+1\right) \times \mathrm{R}_{\mathrm{st}}+1}\right)\right.} \\
&-\left.\left(\frac{\left(\delta^{13} \mathrm{C}_{\text {background }} / 1000+1\right) \times \mathrm{R}_{\mathrm{st}}}{\left(\delta^{13} \mathrm{C}_{\text {background }} / 1000+1\right) \times \mathrm{R}_{\mathrm{st}}+1}\right)\right] \\
& \times \mathrm{C}_{\text {sample }}
\end{aligned}
$$

where $\delta^{13} \mathrm{C}_{\text {background }}$ is the $\delta^{13} \mathrm{C}$ value of the unlabeled sample and $\mathrm{C}_{\text {sample }}$ is the pool size in mole of carbon per gram of dry weight sediment $\left(\mathrm{C} \mathrm{g}^{-1}\right.$ dry wt). 
Table 1. 16S rRNA-targeted oligonucleotide probes used in this study.

\begin{tabular}{|c|c|c|c|c|}
\hline Probe & Sequence $\left(5^{\prime}-3^{\prime}\right)$ & $\% \mathrm{FA}^{*}$ & Specificity & Reference \\
\hline EUB338 & GCT GCC TCC CGT AGG AGT & 25 & most Bacteria & Amann et al. 1990 \\
\hline DELTA495a & AGT TAG CCG GTG CTT CCT & 45 & $\begin{array}{c}\text { most Deltaproteobacteria and } \\
\text { most Gemmatimonadetes }\end{array}$ & Loy et al. 2002 \\
\hline cDELTA495a & AGT TAG CCG GTG CTT CTT & 45 & mompetitor of DELTA495a & Macalady et al. 2006 \\
\hline Dbact653 & TTC CCT CTC CCA TAC TCA & 25 & most Desulfobacteraceae & Miyatake et al. 2009 \\
\hline Dbact653_up_help & CCC CGG AAG TGC AYT TGA WAC & 25 & helper probe for Dbact653 & Miyatake et al. 2009 \\
\hline Dbact653_down_help & GTG GAA TTC CTG GTG TAG AGG & 25 & helper probe for Dbact653 & Miyatake et al. 2009 \\
\hline CYA361 & CCC ATT GCG GAA AAT TCC & 20 & $\begin{array}{l}\text { most Cyanobacteria and many } \\
\text { chloroplast }\end{array}$ & Schönhuber et al. 1999 \\
\hline BG553 & CGC CCA GTA ATT CCG ATT & 60 & $\begin{array}{l}\text { most Betaproteobacteria and } \\
\text { Gammaproteobacteria }\end{array}$ & Miyatake et al. 2013 \\
\hline BG553_up_help & AAC CGC CTR CGN RCG CTT TA & 60 & helper probe for BG553 & Miyatake et al. 2013 \\
\hline BG553_down_help & AAC GCT YGC ACC CTM CTG ATT & 60 & helper probe for BG553 & Miyatake et al. 2013 \\
\hline
\end{tabular}

* Percent formamide (FA) in hybridization buffer for hybridizations at $20^{\circ} \mathrm{C}$.

Excess ${ }^{13} \mathrm{C}$ into bacterial biomass was estimated from the label in bacterial-biomarker PLFA as

$$
\begin{gathered}
\text { Excess }{ }^{13} \mathrm{C}-\text { bacterial biomass }\left(\mathrm{mol}^{13} \mathrm{C} \mathrm{g}^{-1} \text { dry wt }\right)= \\
\sum \text { Excess }{ }^{13} \mathrm{C}_{\text {PLFAbact }} /(0.056 \times 0.28)
\end{gathered}
$$

where ${ }^{13} \mathrm{C}_{\text {PLFAbact }}$ is ${ }^{13} \mathrm{C}$ in bacterial-biomarker PLFA (i14:0, i15:0, a15:0, i16:0, and 18:1 $107 \mathrm{c}$ ), 0.056 represents the average PLFA content in bacteria in terms of carbon and $0.28 \pm 0.04$ is the average fraction of these bacterialbiomarkers PLFA among total PLFA in bacteria-dominated marine sediments (Middelburg et al. 2000). Excess ${ }^{13} \mathrm{C}$ into algal biomass was calculated from the difference between excess ${ }^{13} \mathrm{C}$ into all PLFA and excess ${ }^{13} \mathrm{C}$ into bacterial-biomarker PLFA and also corrected for the typical PLFA content of diatoms:

$$
\begin{aligned}
& \text { Excess }{ }^{13} \mathrm{C}-\text { algal biomass }\left(\mathrm{mol}^{13} \mathrm{C} \mathrm{g}^{-1} \text { dry wt }\right) \\
& =\left(\sum \text { Excess }^{13} \mathrm{C}_{\text {PLFAall }}-\sum \text { Excess }^{13} \mathrm{C}_{\text {PLFAbact }}\right) / 0.035
\end{aligned}
$$

where ${ }^{13} \mathrm{C}_{\text {PLFAall }}$ is ${ }^{13} \mathrm{C}$ in all individual PLFA measured in this study and 0.035 represents the average PLFA content of diatoms (Middelburg et al. 2000). Algal and bacterial biomass was calculated as above in terms of carbon per gram of dry weight sediment using the biomarker PLFA concentrations instead of excess ${ }^{13} \mathrm{C}$.

\section{Results}

Incorporation of ${ }^{13} \mathrm{C}$ in major carbon pools and intermediate metabolites - Concentrations of DIC and TOC in the sediment were $1.2 \pm 0.1 \mu \mathrm{mol} \mathrm{C} \mathrm{g}{ }^{-1}$ dry wt and $309 \pm$ $20 \mu \mathrm{mol} \mathrm{C} \mathrm{g}^{-1}$ dry wt, respectively, throughout the experimental period. Label recovered in the DIC after $4 \mathrm{~h}$ $\left(25 \mathrm{nmol}{ }^{13} \mathrm{C} \mathrm{g}^{-1}\right.$ dry wt; Fig. 1B) was already substantially lower than expected from the total amount of DIC-label that was initially added $\left(600 \mathrm{nmol}{ }^{13} \mathrm{C} \mathrm{g}^{-1}\right.$ dry wt), which was the result of photosynthesis by diatoms and probably also exchange with the atmosphere in this open system. DIC ${ }^{13} \mathrm{C}$-labeling further decreased sharply during the first day of the experiment followed by more gradual decrease until the end of the experiment when almost no ${ }^{13} \mathrm{C}$ label remained (Fig. 1B). Label incorporation in TOC increased sharply during the first low tide and remained approximately constant at $200 \mathrm{nmol}{ }^{13} \mathrm{C} \mathrm{g}^{-1}$ dry wt during the first $3 \mathrm{~d}$ of the experiment, except for a small peak after $12 \mathrm{~h}$. Finally, the label in TOC decreased to $120 \mathrm{nmol}^{13} \mathrm{C} \mathrm{g}^{-1}$ dry wt on day 5 (Fig. 1C). These data suggest a rapid incorporation of the ${ }^{13} \mathrm{C}$-DIC label by the benthic primary producers during the pulse-labeling period followed by minimal losses for the remainder of the experiment until day 5 .

The bulk carbohydrates content was $27.1 \pm 1.7 \mu \mathrm{mol} \mathrm{Cg}^{-1}$ dry wt throughout the experimental period and showed little variation (Fig. 2A). Glucose and galactose were the two major components and their contributions remained constant $(\sim 30 \%$ and $15 \%$, respectively). Water-extractable carbohydrates accounted for $\sim 10 \%$ of the bulk carbohydrates and varied substantially during the experiment (Fig. 2B). The concentration of water-extractable carbohydrates was lower for the $12 \mathrm{~h}$ and day 3 samplings. The concentration of EDTA-extractable carbohydrates was $\sim$ 2-3 times lower than the water-extractable carbohydrates and remained approximately constant during the experiment except on the day 3 when values decreased by a factor of 2-3 (Fig. 2C). Glucose was the main carbohydrate in both the water-extractable EPS and EDTAextractable fractions explaining between $30 \%$ and $70 \%$ of the total carbohydrates.

The limited turnover of the ${ }^{13} \mathrm{C}$-label in the TOC pool during the experimental period was not seen in the bulk and water-extractable carbohydrates. Excess ${ }^{13} \mathrm{C}$ in bulk, waterextractable, and EDTA-extractable carbohydrates were highest between $4 \mathrm{~h}$ and $12 \mathrm{~h}$ after labeling and decreased with time (Fig. 2D-F). More than $90 \%$ of ${ }^{13} \mathrm{C}$ labeling was recovered in glucose in the three analyzed pools. Initially, ${ }^{13} \mathrm{C}$ content in the water-extractable carbohydrates explained about half of the ${ }^{13} \mathrm{C}$ label of the bulk carbohydrates. Labeling of the EDTA-extractable carbohydrates was substantially lower (one order of magnitude) than of the water-extractable carbohydrates. The label decreased faster in the water-extractable carbohydrates than in the bulk and EDTA-extractable carbohydrates, and had 

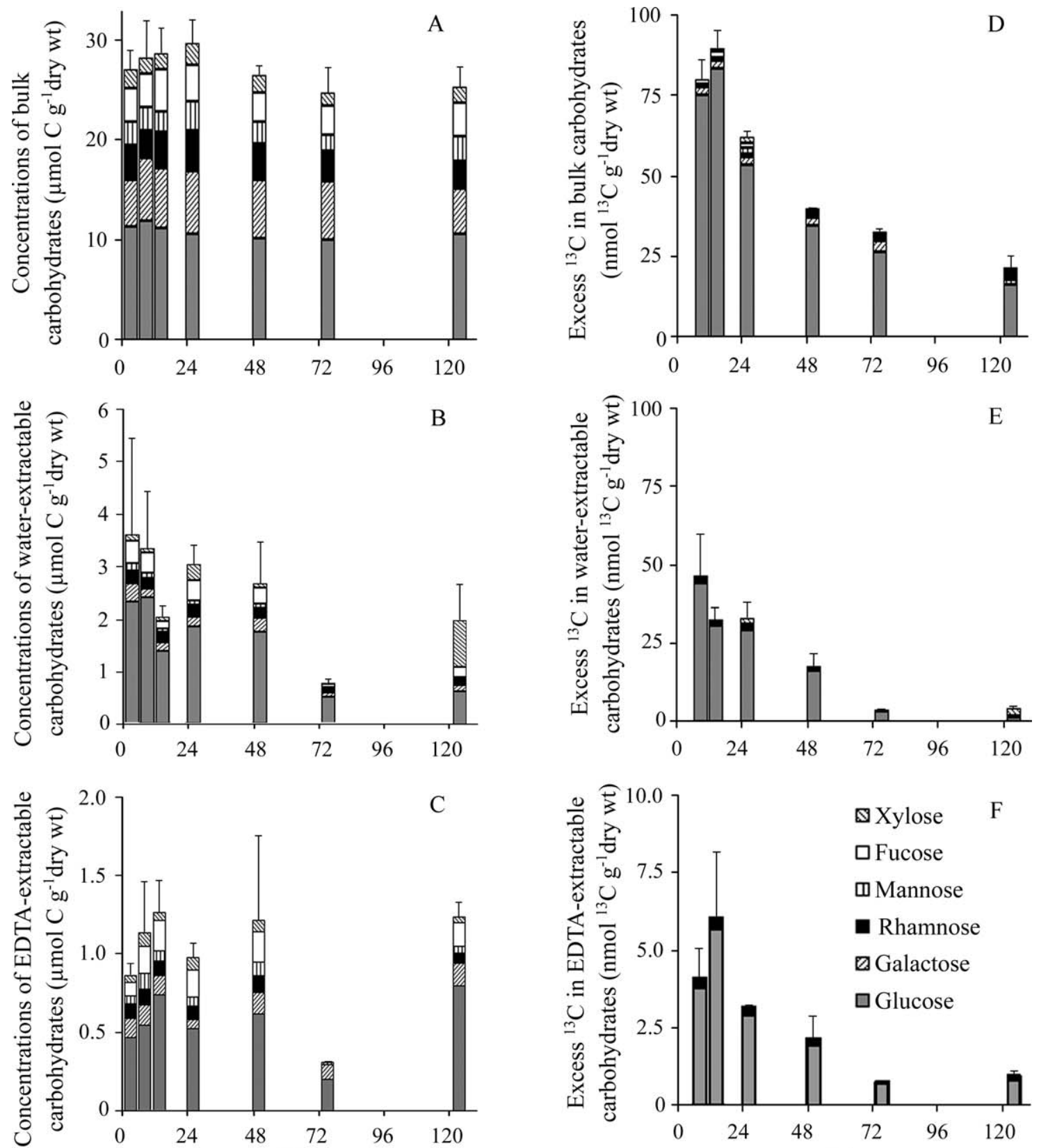

(h)

(h)

Fig. 2. Monosaccharide composition and concentrations of (A) bulk, (B) water-extractable, and (C) EDTA-extractable carbohydrates are shown together with excess ${ }^{13} \mathrm{C}$ in (D) bulk, (E) water-extractable, and (F) EDTA-extractable carbohydrates. Average values $(n=2)$ are shown for individual carbohydrate data and error bars indicate the range in the summed data.

almost disappeared at the end of the experiment. Label incorporation in carbohydrates other than glucose was much lower and remained more-or-less constant. Hence, the decrease in ${ }^{13} \mathrm{C}$-label incorporation in bulk carbohydrates between $4 \mathrm{~h}$ and day 5 was mainly due (by about $75 \%$ ) to the decrease of ${ }^{13} \mathrm{C}$ label in glucose from waterextractable carbohydrates and to a much lesser extend by the EDTA-extractable carbohydrates.

SCOA in the pore water was the most dynamic pool of metabolites analyzed during this experiment. SCOA detected in this study were formate, acetate, oxalate, malate, lactate, and succinate. Lactate and succinate could not be separated sufficiently by our HPLC protocol and are therefore reported together. The propionate peak overlapped with an unknown peak. Significant changes in the concentrations of lactate+succinate and acetate were observed. Other SCOA detected in this study had low and constant concentrations during the experiment (2030 nmol $\mathrm{C} \mathrm{g}^{-1}$ dry wt) and showed limited labeling; hence, only lactate+succinate and acetate are depicted in Fig. 3. Concentrations of lactate+succinate and acetate were similar at the start of the experiment, but lactate+succinate was higher than acetate after addition of the tracer and increased again on day 3. The concentration of 

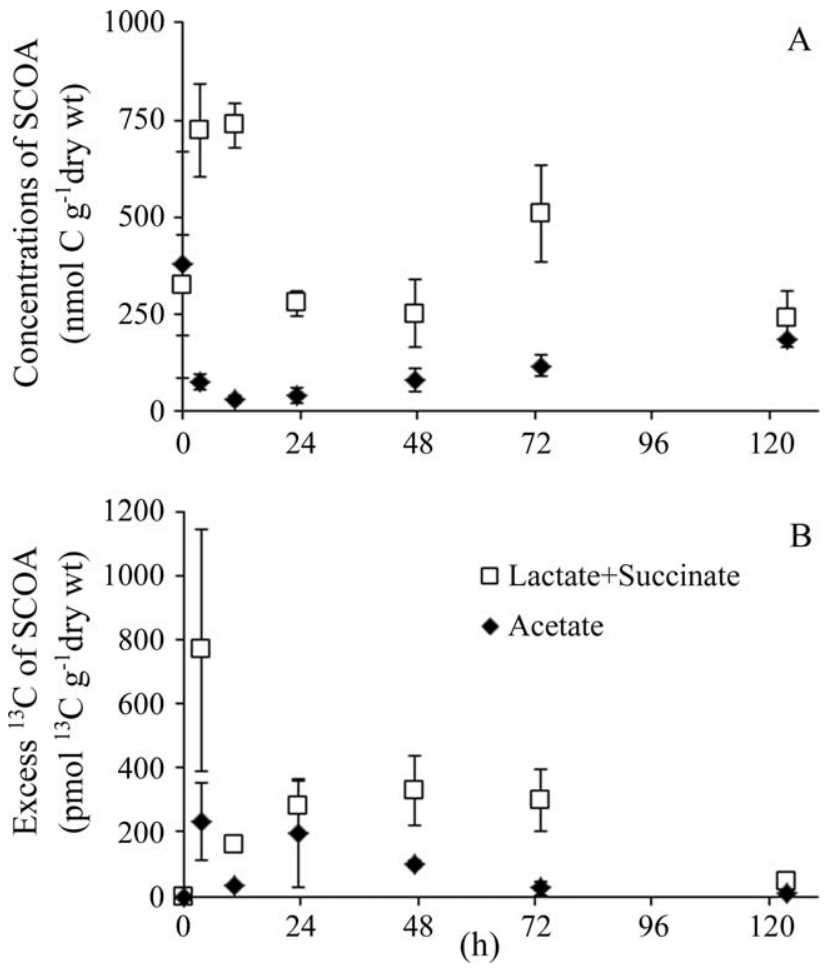

Fig. 3. (A) Average concentration and (B) excess ${ }^{13} \mathrm{C}$ of short-chain organic acids (SCOA: lactate+succinate and acetate) in the pore water $(n=2)$. Error bars show the range in the duplicate data.

acetate was highest at $0 \mathrm{~h}$ followed by sharp decrease at $4 \mathrm{~h}$, then gradually increased to day 5. Pore-water concentrations of acetate (range 100-1200 $\mathrm{nmol} \mathrm{C} \mathrm{mL}^{-1}$ ) and lactate+succinate (range 750-2300 nmol C mL $\mathrm{m}^{-1}$ ) were high. ${ }^{13} \mathrm{C}$-label incorporation was only detected for lactate+succinate and acetate, and was higher in lactate+succinate than in acetate (Fig. 3B). Excess ${ }^{13} \mathrm{C}$ in lactate+succinate and acetate was highest at $4 \mathrm{~h}$, and then significantly decreased at $12 \mathrm{~h}$ followed by gradual increase before diminishing at day 5 .

Microbial community composition-Throughout the $5 \mathrm{~d}$ of the experiment, the sediment was covered by a diatom mat. Chlorophyll $a$ content was $17.2 \pm 0.9 \mu \mathrm{g} \mathrm{g}^{-1}$ dry wt, and the content of fucoxanthin (a marker for diatoms [Wright and Jeffrey 1987; Dijkman and Kromkamp 2006]) was $6.1 \pm 0.3 \mu \mathrm{g} \mathrm{g}^{-1}$ dry wt throughout the experiment, indicating a high proportion of diatom biomass. The $16 \mathrm{~S}$ rRNA clone library derived from total RNA reflects the metabolically active community and confirmed the dominance of benthic diatoms ( $44 \%$ of the sequences belonged to chloroplasts of benthic diatoms), whereas cyanobacterial clones were fewer (6\%; Fig. 4). Moreover, the content of specific biomarkers PLFA for diatoms was much higher $\left(86.5 \pm 9.3\right.$ and $495.5 \pm 110.4 \mathrm{nmol} \mathrm{C} \mathrm{g}{ }^{-1}$ dry wt for 16 PUFA and 20:5 03 , respectively) than for Cyanobacteria $\left(51.8 \pm 10.1\right.$ and $30.9 \pm 5.5 \mathrm{nmol} \mathrm{C} \mathrm{g}{ }^{-1}$ dry wt for 18

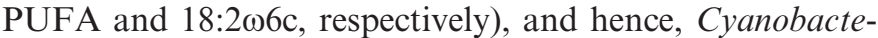
ria contributed much less to the microphytobenthic biomass than diatoms (Fig. 5). The 16S rRNA clone library showed that Gammaproteobacteria (21\% of the sequences), Bacteroidetes (8\%), and Deltaproteobacteria $(7 \%)$ were the major groups in the bacterial community in addition to the Cyanobacteria (Fig. 4). EUB338 was used as a general bacterial probe in this study and it covered most of the Bacteria detected in the clone library and only missed the Planctomycetes. The combination of the other specific probes covered $77 \%$ of the $16 \mathrm{~S}$ rRNA targeted by the EUB338 probe but did not include the Bacteroidetes. The specificity of each oligonucleotide probe used with Mag-SIP was $>90 \%$.

Incorporation of ${ }^{13} \mathrm{C}$ into biomarkers-Label $\left({ }^{13} \mathrm{C}\right)$ incorporation in PLFA biomarkers and in 16S rRNA of

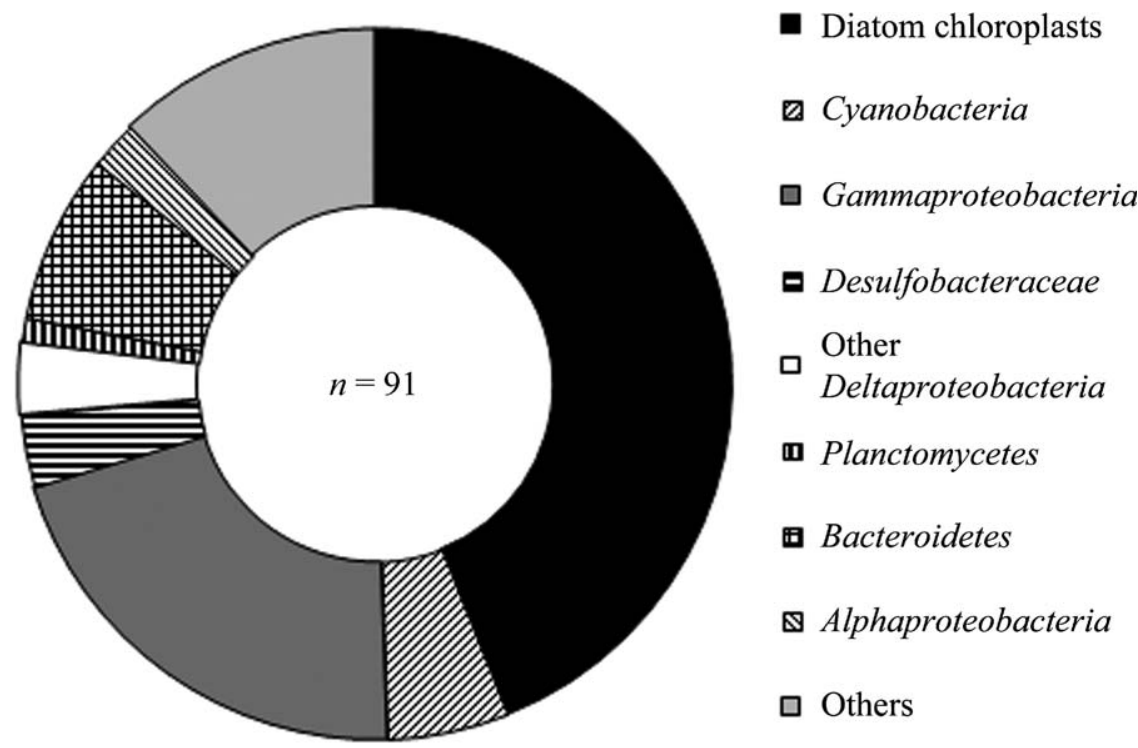

Fig. 4. Proportion of clones affiliated with major phylogenetic groups in the clone library derived from reversed-transcribed $16 \mathrm{~S}$ rRNA. Total numbers of clones sequenced are indicated as $n$. 


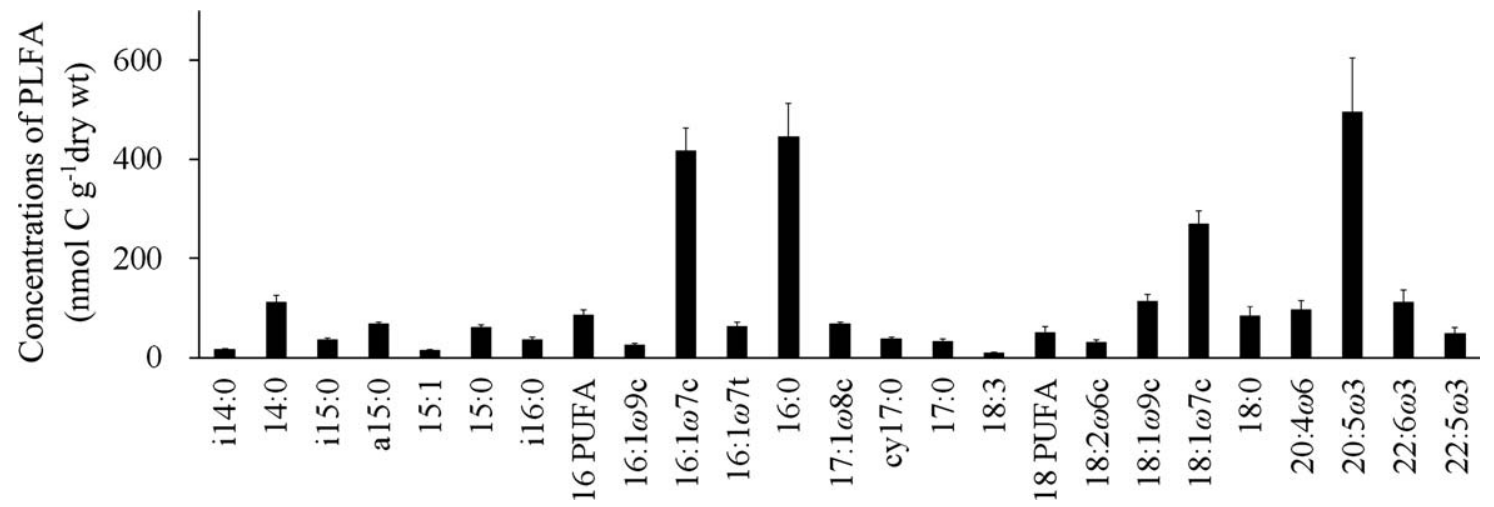

Fig. 5. Average concentration of individual PLFA in unlabeled sediment $(0 \mathrm{~h}, n=2)$. Error bars indicate the range in the duplicate data.

specific bacterial groups was measured in order to trace the carbon transfer from diatoms to heterotrophic bacteria. The total amount of RNA extracted per dry weight unit of sediment was constant throughout the experiment (10.9 \pm $1.5 \mu \mathrm{g}$ RNA $\mathrm{g}^{-1}$ dry wt), as was the case with PLFA (3.22 $\pm 0.35 \mu \mathrm{mol} \mathrm{C} \mathrm{g}^{-1}$ dry $\left.\mathrm{wt}\right)$. The PLFA content in diatoms and bacteria is relatively constant and conversion factors are known that can be used to infer the actual amount of label in their biomass (Middelburg et al. 2000; Fig. 6A,B). However, 16S rRNA cannot be used in this way because the number of ribosomes varies per cell depending on the species, growth rate, and environmental conditions (Flärdh et al. 1992; Kerkhof and Kemp 1999). Therefore, ${ }^{13 C}$ incorporation in $16 \mathrm{~S}$ rRNA was expressed as $\Delta \delta^{13} \mathrm{C}$, which is a measure of specific ${ }^{13} \mathrm{C}$-label incorporation into $16 \mathrm{~S}$ rRNA of the target group relative to the unlabeled $16 \mathrm{~S}$ rRNA of this group.

Based on PLFA data, ${ }^{13} \mathrm{C}$ labeling in diatom biomass rapidly increased during the first $12 \mathrm{~h}$ and subsequently decreased somewhat until day 1, which again was followed by an secondary increase until day 3 (Fig. 6B). The ${ }^{13} \mathrm{C}$ labeling in bacterial biomass also increased rapid during the first $12 \mathrm{~h}$ followed by a slower increase until day 3 and a decrease at day 5 (Fig. 6B). Note that hardly any ${ }^{13}$ C-DIC label remained in the sediment after the first day (Fig. 1). This suggests that the increase in label incorporation in the diatoms and bacteria after day 1 can be attributed to the consumption of the ${ }^{13} \mathrm{C}$-labeled organic pool produced during the first $4 \mathrm{~h}$ of the experiment. This second increase in ${ }^{13} \mathrm{C}$-label incorporation in diatoms and bacteria (Fig. 6B) coincided with the decrease in ${ }^{13} \mathrm{C}$-labeled glucose originating from the water-extractable carbohydrates (Fig. 2E). There was no detectable label incorporation in PLFA in dark incubations (data not shown), indicating that dark fixation by chemoautotrophic bacteria and anaplerotic carbon fixation by heterotrophs were not important. Hence, the PLFA data suggest a rapid transfer of organic carbon from diatoms to bacteria in the first $12 \mathrm{~h}$, followed by a slower secondary utilization by both diatoms and bacteria of primarily ${ }^{13} \mathrm{C}$-labeled glucose from the water-extractable carbohydrates.

Label incorporation in $16 \mathrm{~S}$ rRNA that was captured with group-specific oligonucleotide probes also showed two maxima, the first on day 1 and the second on day 3
(Fig. 7A). Unlabeled controls of $16 \mathrm{~S}$ rRNA possessed $\delta^{13} \mathrm{C}$ values between $-15 \%$ and $-20 \%$, which is within the typical range for marine benthic diatoms and bacteria (Coffin et al. 1990; Boschker and Middelburg 2002). The $\Delta \delta^{13} \mathrm{C}$ value of diatom and Cyanobacteria $16 \mathrm{~S}$ rRNA represents primarily the label incorporation by diatoms
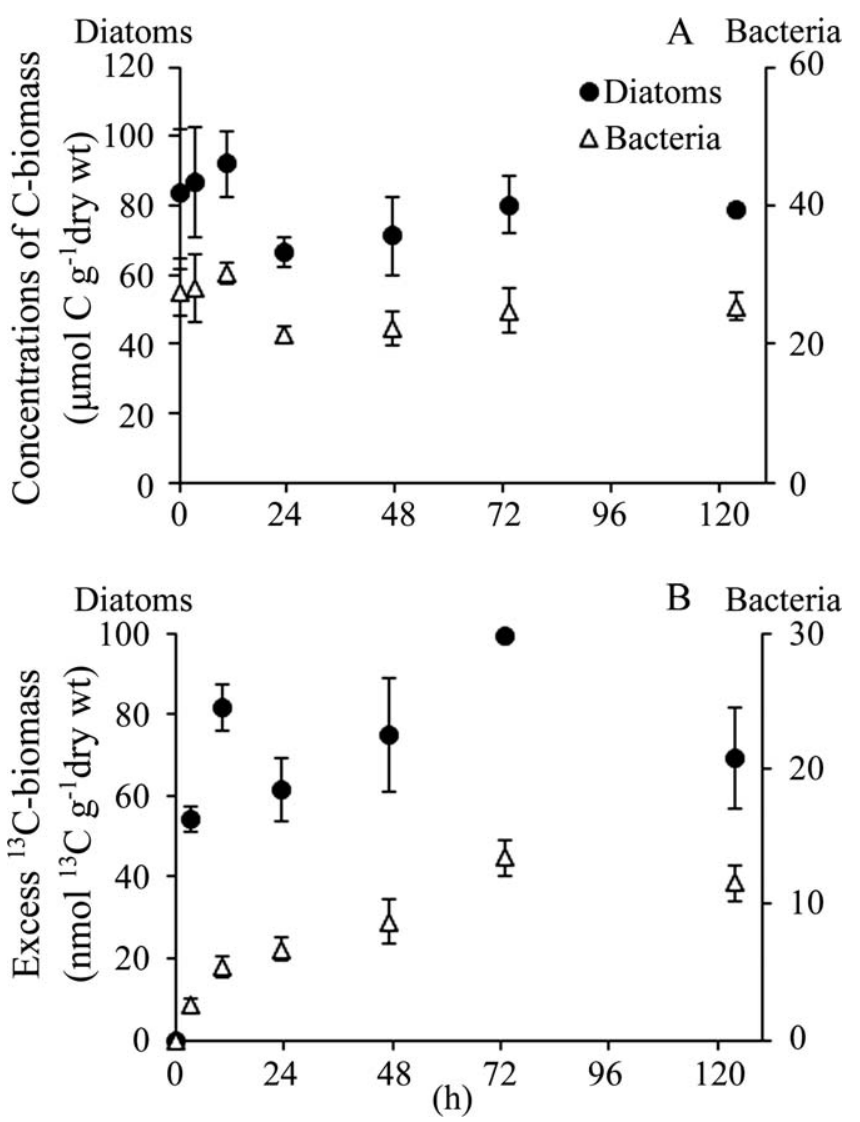

Fig. 6. (A) Average concentration of biomass carbon and (B) excess ${ }^{13} \mathrm{C}$ in diatoms and in bacteria calculated from concentrations of biomarker PLFA and ${ }^{13} \mathrm{C}$ label incorporated into PLFA, respectively $(n=2)$. The bacterial-biomarker PLFA used are

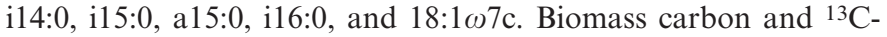
label incorporation of diatoms were calculated from the difference between total PLFA and bacterial PLFA. Error bars show the range in the duplicate data. 

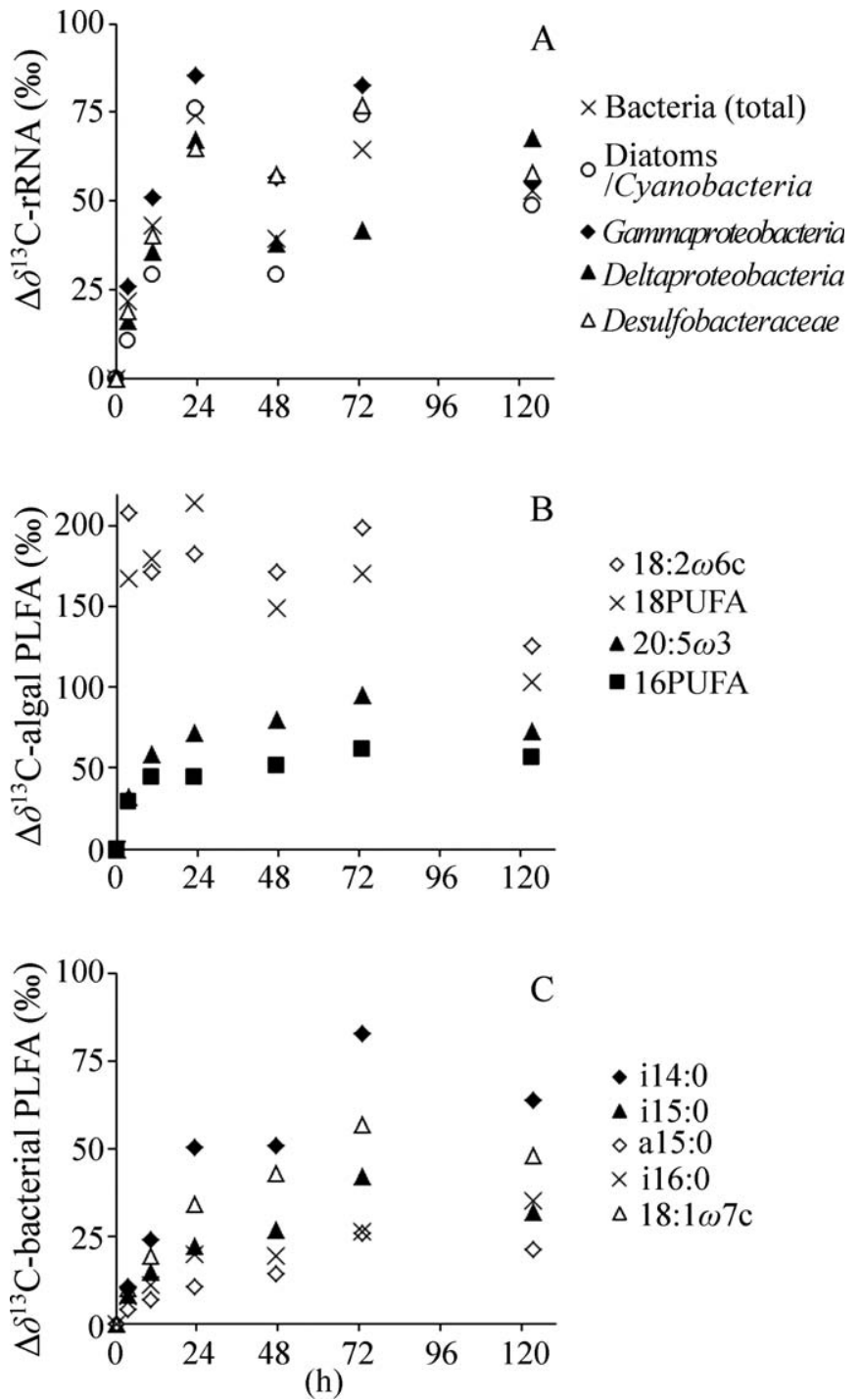

Fig. 7. $\quad \Delta \delta^{13} \mathrm{C}$ values of (A) rRNA captured with the nested set of oligonucleotide probes used in the Mag-SIP method, (B) representative biomarker PLFA for microphytobenthos (diatoms,

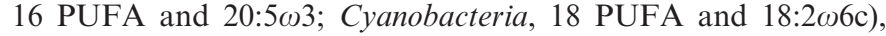
and (C) representative biomarker PLFA for heterotrophic bacteria. Only average values are shown $(n=2)$. Error bars are not included for clarity; however, differences between duplicates were generally low and maximum $31 \%$ and $34 \%$ of mean for $16 \mathrm{~S}$ rRNA and PLFA, respectively.

because the Cyanobacteria biomass was low. Remarkably, $\Delta \delta^{13} \mathrm{C}$ ratios of all captured $16 \mathrm{~S}$ rRNA fractions were similar and showed the same trend during the experiment. For instance, the difference in the $\Delta \delta^{13} \mathrm{C}$ pattern of the total bacteria (EUB338-captured 16S rRNA) and of the family Desulfobacteraceae (Dbact653-captured 16S rRNA), which comprised only $3 \%$ of the clone library, was small. Only Deltaproteobacteria $16 \mathrm{~S}$ rRNA showed a delay in accumulating label during the second part of the experiment. On day 3, the label in Deltaproteobacteria $16 \mathrm{~S}$ rRNA was less than in the other captured 16S rRNAs and reached a maximum only on day 5 at the end of the experiment.
In order to compare the label incorporation in $16 \mathrm{~S}$ rRNA and PLFA, the $\Delta \delta^{13} \mathrm{C}$ values of several representative biomarker PLFAs for microphytobenthos (16 PUFA, 18 PUFA, 18:2 $\omega 6 \mathrm{c}$, and 20:5 $\omega 3$ ) and biomarker PLFAs for heterotrophic bacteria (i14:0, i15:0, a15:0, i16:0, and 18:1 $\omega 7 \mathrm{c}$ ) are depicted in Fig. 7B and 7C. Biomarker PLFA $\Delta \delta^{13} \mathrm{C}$ values for diatoms (16 PUFA and 20:5 Cyanobacteria (18 PUFA and 18:206c) showed different trends (Fig. 7B). Labeling in biomarker PLFA for Cyanobacteria initially increased sharply followed by a gradual decrease until the end of the experiment. In contrast, diatom biomarker PLFA labeling showed a fast increase until $12 \mathrm{~h}$ followed by a more gradual increase until day 3 , and it then decreased slightly. Although $\Delta \delta^{13} \mathrm{C}$ values of biomarker PLFA for Cyanobacteria were higher than for diatoms, excess ${ }^{13} \mathrm{C}$ in diatom PLFA was much higher because diatoms were the dominant primary producers at the study site. Representative biomarker PLFA for bacteria showed similar labeling patterns as biomarker PLFA for diatoms (16 PUFA and 20:5 03 ) with a fast increase during the first day of the experiment followed by a slower labeling until a maximum on day 3 (Fig. 7C). Furthermore, the highest $\Delta \delta^{13} \mathrm{C}$ values in the different captured $16 \mathrm{~S}$ rRNA and biomarker PLFAs were at a similar range $(50-100 \%$ ) except for cyanobacterial biomarker PLFAs, which was, however, only a minor part of the microbial community. To summarize, the combined results of the biomarker labeling suggest that carbon fixed by diatoms was rapidly and evenly utilized by the heterotrophic bacterial community.

\section{Discussion}

In this study, the transfer of carbon from benthic diatoms to the heterotrophic bacterial community was traced by following the ${ }^{13} \mathrm{C}$-labeling dynamics in different biologically derived compounds and major groups within the microbial community. We demonstrated that Mag-SIP can be used to trace carbon flow in a benthic diatom mat and we measured the ${ }^{13} \mathrm{C}$-label incorporation in heterotrophic bacteria that were identified to the family level. Other in situ ${ }^{13} \mathrm{C}$-labeling studies used PLFA (Middelburg et al. 2000; Evrard et al. 2008; Oakes et al. 2012) and D-alanine (Veuger et al. 2006) as biomarkers, but these have a phylogenetic resolution that does not exceed the level of domains or kingdoms. In addition, we also measured ${ }^{13} \mathrm{C}$ labeling in bulk, water-extractable, and EDTA-extractable carbohydrates as well as SCOA in pore water using recently developed LC-IRMS methods to determine which intermediates were important in the transfer of organic matter from diatoms to heterotrophic bacteria. Although the relationship between diatom carbohydrates exudates and the heterotrophic bacterial community have been studied in intertidal sediments (Hanlon et al. 2006; Haynes et al. 2007; Bellinger et al. 2009; Oakes et al. 2012; Taylor et al. 2013), we included SCOA as important intermediates in the anaerobic degradation of diatom material (McKew et al. 2013). The results were used to construct a conceptual model of the transfer of carbon in the diatom mat (Fig. 8A) and are summarized in a ${ }^{13} \mathrm{C}$-budget (Fig. $8 \mathrm{~B}$ ). We propose two main events during which organic carbon was 
A
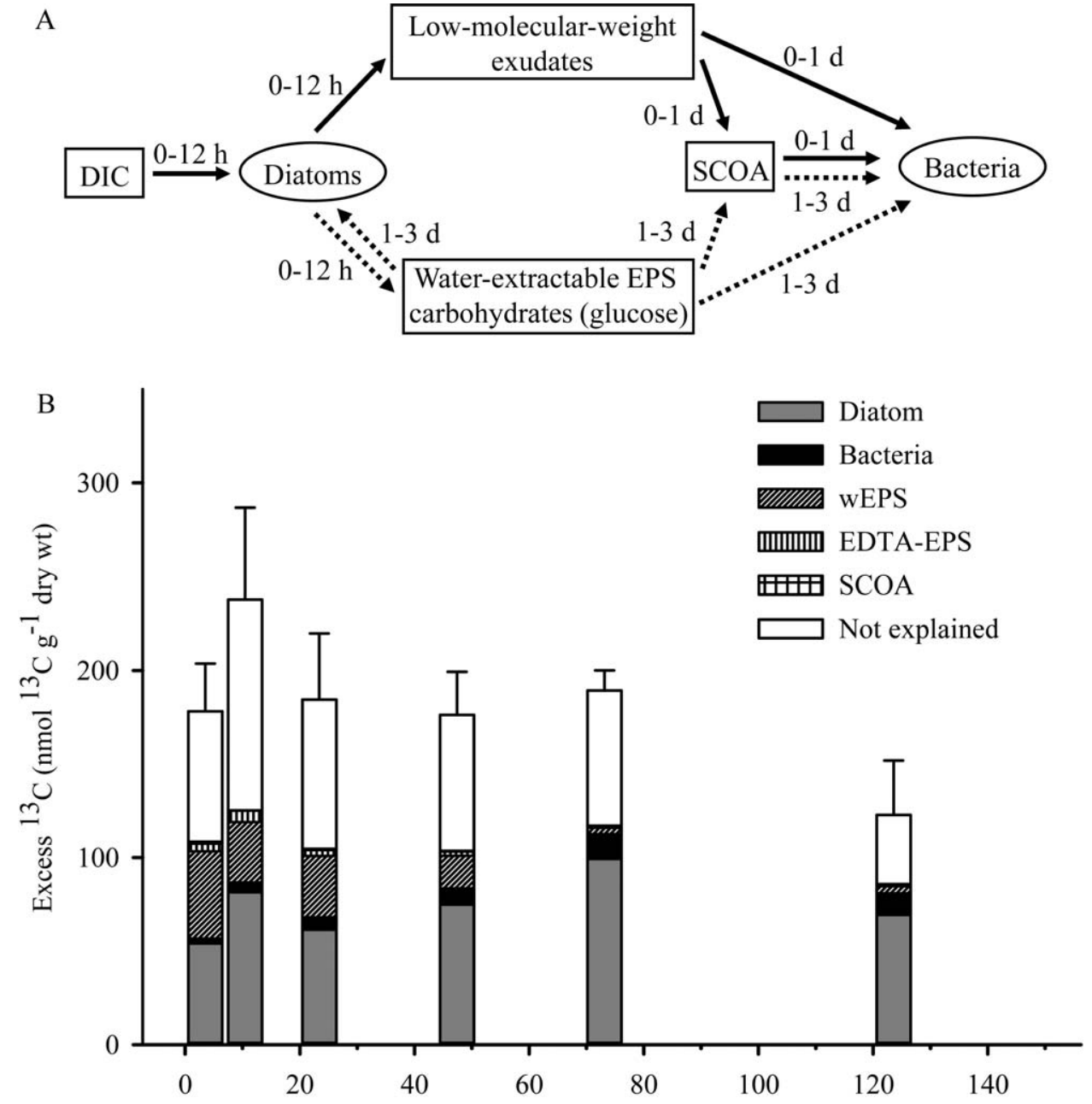

(h)

Fig. 8. (A) Conceptual model of carbon flow in the diatom mat based on ${ }^{13}$ C-labeling data. Organisms are indicated by oval boxes and substances by square boxes. Solid arrows indicate the short-term carbon flow and dotted arrows indicate long-term carbon flow. Numbers correspond to the time after labeling. SCOA stands for short-chain organic acids. (B) ${ }^{13} \mathrm{C}$ budget at the different sampling points of the experiment. 'Not explained' is the fraction of the ${ }^{13} \mathrm{C}$ TOC labeling not explained by the sum of the labeling in the individual pools. Average data of the individual pools are shown $(n=2)$, and error bars indicate the range in the summed data.

transferred from benthic diatoms to heterotrophic bacteria, which operated on different time scales.

The ${ }^{13} \mathrm{C}$-label incorporation in PLFA and $16 \mathrm{~S}$ rRNA biomarkers suggested that there was a fast transfer of organic substrates from diatoms to heterotrophic bacteria already during the first day of the experiment (Figs. 6, 7, 8). This initial fast transfer was probably the result of the utilization of low-molecular-weight $(<800 \mathrm{Da})$ organic compounds exuded by diatoms that could be directly utilized by heterotrophic bacteria. These low-molecularweight exudates may include a wide range of different compounds including monomeric carbohydrates, amino acids and organic acids, some of which may be difficult to track with the currently available ${ }^{13} \mathrm{C}$-methods due to their fast turn-over and typical low concentrations. However, the fast transfer of label coincided with a sharp peak in SCOA labeling (Fig. 3), which indicated that some low-molecular- weight exudates produced by the diatoms (such as glucose) were quickly fermented by anaerobic bacteria. Fermentation products such as acetate and lactate are important substrates for anaerobic bacterial communities (Jørgensen 2006; McKew et al. 2013). During photosynthesis, carbon assimilated by the diatoms is in part stored as intracellular glucan that consists of $90 \%$ glucose (Underwood et al. 2004) and excess carbon is exuded from the cells as waterextractable carbohydrates (Smith and Underwood 2000; de Brouwer and Stal 2001). At daytime in intertidal sediments, up to $80 \%$ of this water-extractable carbohydrate can be mono- and oligo-saccharides (Underwood et al. 1995; Underwood and Smith 1998; Smith and Underwood 2000), which are readily available for heterotrophic bacteria and may explain the initial fast transfer.

Between $12 \mathrm{~h}$ and $24 \mathrm{~h}$, the label recovered in waterextractable carbohydrates explained $70 \%$ of the label in the 
bulk carbohydrates (Fig. 2D, E) and between $20 \%$ and $25 \%$ of the label in TOC (Fig. 1C, 6B). Among the carbohydrates, most of the ${ }^{13} \mathrm{C}$ label was recovered in glucose $(>90 \%)$, which was highest at $4 \mathrm{~h}$ after labeling and subsequently decreased sharply until it had disappeared almost completely by day 3 (Fig. 2D-F), explaining most of the total loss of labeled glucose in the diatom mat. Glucose is the first compound synthesized by phototrophic organisms and it was therefore not surprising that it had the highest label, confirming observations by Bellinger et al. (2009) and to a lesser extent by Oakes et al. (2010). Water-extractable EPS carbohydrates were therefore major intermediates released by the diatoms as detected in this study.

After the initial fast transfer of organic matter from diatoms to heterotrophic bacteria, label incorporation into both diatoms and heterotrophic bacteria proceeded more slowly from day 1 until day 3 (Figs. 6, 7, 8). Almost no label was left in the DIC between day 1 and 3 and, hence, the second label incorporation must have been due to organic carbon utilization that was initially produced by the diatoms. This second peak of label incorporation in bacteria coincided with the disappearance of label in water-extractable carbohydrates (Fig. 2E) and also with the second increase of label in SCOA (Fig. 3B). It was therefore concluded that the origin of this second labeling between day 1 and 3 was based on the consumption of the EPS fraction of water-extractable carbohydrates that was exuded during the first day after labeling and was partially fermented under anaerobic conditions. Approximately $15 \%$ or more of the diatom exudates in the light is EPS (Smith and Underwood 2000; Underwood and Paterson 2003). The chemical properties of EPS make them more recalcitrant to degradation in contrast to the low-molecularweight exudates. Bacteria can utilize high-molecular-weight compounds such as EPS only after extracellular enzymatic hydrolysis to low-molecular-weight compounds (Fuchs et al. 1998; Hunter et al. 2006), which would explain the slower labeling rate of bacterial PLFA and 16S rRNA between day 1 and 3 (Fig. 7A,C). Surprisingly, we also detected this secondary labeling in the diatoms, which may be attributed to the heterotrophic metabolism of these organisms because hardly any DIC ${ }^{13} \mathrm{C}$ label was left. This second labeling coincided with the decrease of labeling in carbohydrates, which suggested that the diatoms used EPS as an external carbon storage as has been shown for pure cultures of diatoms (Staats et al. 2000; de Brouwer and Stal 2001) and for slurry incubation to which diatom-derived EPS was added (Taylor et al. 2013). Miyatake et al. (2013) recently showed that benthic diatoms in coastal sediment incorporated a variety of organic substrates, and active heterotrophic growth of diatom cultures on glucose is well-known (Lewin and Hellebust 1976; Admiraal and Peletier 1979). Alternatively, it is also possible that diatoms gradually reincorporated intracellular storage glucans into cell materials. This was not specifically investigated in our study but it is well-known that diatoms utilize these reserve carbohydrates during the dark (Smith and Underwood 2000). For instance, Smith and Underwood (2000) reported that pure cultures of diatoms produced EPS in the dark from intracellular glucan during up to $3 \mathrm{~d}$, which agrees with the second peak of label incorporation of diatoms that we observed.

We used both PLFA analyses and Mag-SIP to determine the labeling dynamics of major microbial groups in the diatom mat. Labeling levels and timing were mostly similar, although labeling of $16 \mathrm{~S}$ rRNA seemed to be more dynamic than that of PLFA (Fig. 7). The highest $\Delta \delta^{13} \mathrm{C}$ values of diatom PLFA and bacterial PLFA were in the same range at $50-100 \%$ in this study. This is consistent with the study of Bellinger et al. (2009), but disagrees with those of Middelburg et al. (2000) and Evrard et al. (2008), who reported an approximately five-fold higher labeling in terms of $\Delta \delta^{13} \mathrm{C}$ values in diatom PLFA than in bacterial PLFA. Another difference is that Middelburg et al. (2000) and Evrard et al. (2008) reported a much faster decay of total labeling stocks. A possible reason for these differences is that our experiment and that of Bellinger et al. (2009) were done early in spring when thick diatom mats are present, whereas the other studies were done later in the season. In our study, macrofauna had not yet fully developed and therefore the grazing pressure was low. Hence, the diatom mat was at a climax with high biomass and limited growth, and a close coupling between the diatoms and the heterotrophic bacterial community.

Given the importance of water-extractable carbohydrates as an intermediate in diatom mats, we expected that specialized bacteria would be involved in the coupling between diatoms and bacteria (Taylor et al. 2013). However, our results suggest that all major groups within the heterotrophic bacterial community equally utilized the diatom-derived organic matter because the labeling of $16 \mathrm{~S}$ rRNA captured by all different oligonucleotide probes was more or less the same throughout the experiment (Fig. 7). Only the labeling of the Deltaproteobacteria $16 \mathrm{~S}$ rRNA was somewhat slower compared with other groups, but this was only the case between day 1 and 5. The Deltaproteobacteria in the diatom mat are mostly related to sulfate-reducing bacteria and the slower labeling could be due to the fact that their substrates had first to be produced by fermentation under anaerobic conditions by other members of the bacterial community (Miyatake et al. 2013). The even labeling between different bacterial groups may be explained by a combination of diatom primary production dominating heterotrophic carbon cycling in this sediment and a wide variety of exudates produced by diatoms (although our results indicate that glucose in water-extractable EPS was a major intermediate). Taylor et al. (2013) reported high label incorporation by diatoms, Alpha, and Gammaproteobacteria from isolated water-extractable EPS with RNA-SIP, but also showed the even labeling of general bacterial PLFA with PLFA-SIP. Miyatake et al. (2013) also reported the even utilization of glucose (and other organic substrates) by most major groups in the microbial community of the sediment surface layer $(0-2 \mathrm{~cm})$. This also hints at a limited specialization of the bacterial community in these intertidal sediments; however, we cannot exclude that there may still be specialized bacteria within the relatively broad phylogenetic groups that were targeted in our study (Taylor et al. 2013). We conclude, therefore, that the heterotrophic bacterial community relies to a similar extent on the organic 
carbon produced by the diatoms, resulting in a closely coupled microbial food web.

\section{Acknowledgments}

We thank Peter van Breugel, Marco Houtekamer, and Veronique Confurius-Guns for assistance with the ${ }^{13} \mathrm{C}$ stable isotope and molecular analysis, and two anonymous reviewers for their constructive remarks. This work was supported by Netherlands Organisation for Scientific Research (NWO) Vidi grant to HTSB.

\section{References}

Admiraal, W., and H. Peletier. 1979. Influence of organic compounds and light limitation on the growth rate of estuarine benthic diatoms. Brit. J. Phycol. 14: 197-206, doi:10.1080/00071617900650211

Amann, R. I., B. J. Binder, R. J. Olson, S. W. Chisholm, R. Devereux, and D. A. Stahl. 1990. Combination of $16 \mathrm{~S}$ rRNA-targeted oligonucleotide probes with flow cytometry for analyzing mixed microbial populations. Appl. Environ. Microbiol. 56: 1919-1925.

Bellinger, B. J., G. J. C. Underwood, S. E. Ziegler, and M. R. GRETZ. 2009. Significance of diatom-derived polymers in carbon flow dynamics within estuarine biofilms determined through isotopic enrichment. Aquat. Microb. Ecol. 55: 169-187, doi:10.3354/ame01287

Boschker, H. T. S. 2004. Linking microbial community structure and functioning: Stable isotope $\left({ }^{13} \mathrm{C}\right)$ labeling in combination with PLFA analysis, p. 1673-1688. In G. A. Kowalchuk, F. J. de Bruijn, I. M. Head, A. D. Akkermans, and J. D. van Elsas [eds.], Molecular microbial ecology manual II. Kluwer Academic.

- J. F. C. de Brouwer, and T. E. Cappenberg. 1999. The contribution of macrophyte-derived organic matter to microbial biomass in salt-marsh sediments: Stable carbon isotope analysis of microbial biomarkers. Limnol. Oceanogr. 44: 309-319, doi:10.4319/1o.1999.44.2.0309

, And J. J. Middelburg. 2002. Stable isotopes and biomarkers in microbial ecology. FEMS Microbiol. Ecol. 40: 85-95, doi:10.1111/j.1574-6941.2002.tb00940.x

, T. C. W. Moerdijk-Poortvliet, P. van Breugel, M. Houtekamer, And J. J. Middelburg. 2008. A versatile method for stable carbon isotope analysis of carbohydrates by highperformance liquid chromatography/isotope ratio mass spectrometry. Rap. Com. Mass Spectrom. 22: 3902-3908, doi:10.1002/rcm.3804

Bühring, S. I., M. Elvert, And U. Witte. 2005. The microbial community structure of different permeable sandy sediments characterized by the investigation of bacterial fatty acids and fluorescence in situ hybridization. Environ. Microbiol. 7: 281-293, doi:10.1111/j.1462-2920.2004.00710.x

Coffin, R. B., D. J. Velinsky, R. Devereux, W. A. Price, and L. A. Cifuentes. 1990. Stable carbon isotope analysis of nucleic acids to trace sources of dissolved substrates used by estuarine bacteria. Appl. Environ. Microbiol. 56: 2012-2020.

De Brouwer, J. F. C., AND L. J. Stal. 2001. Short-term dynamics in microphytobenthos distribution and associated extracellular carbohydrates in surface sediments of an intertidal mudflat. Mar. Ecol. Prog. Ser. 218: 33-44, doi:10.3354/meps 218033

Dijkman, N. A., And J. C. Kromkamp. 2006. Phospholipidderived fatty acids as chemotaxonomic markers for phytoplankton: Application for inferring phytoplankton composition. Mar. Ecol. Prog. Ser. 324: 113-125, doi:10.3354/ meps 324113
Evrard, V., P. L. M. Cook, B. Veuger, M. Huettel, and J. J. Middelburg. 2008. Tracing carbon and nitrogen incorporation and pathways in the microbial community of a photic subtidal sand. Aquat. Microb. Ecol. 53: 257-269, doi:10.3354/ame01248

Flärdh, K., P. S. Cohen, and S. KJelleberg. 1992. Ribosomes exist in large excess over the apparent demand for protein synthesis during carbon starvation in marine Vibrio sp. strain CCUG 15956. J. Bacteriol. 174: 6780-6788.

Fuchs, B. M., F. O. Glöckner, J. Wulf, and R. Amann. 2000. Unlabeled helper oligonucleotides increase the in situ accessibility to $16 \mathrm{~S}$ rRNA of fluorescently labeled oligonucleotide probes. Appl. Environ. Microbiol. 66: 3603-3607, doi:10.1128/AEM.66.8.3603-3607.2000

, G. Wallner, W. Beisker, I. Schwippl, W. Ludwig, and R. AMANN. 1998. Flow cytometric analysis of the in situ accessibility of Escherichia coli 16S rRNA for fluorescently labeled oligonucleotide probes. Appl. Environ. Microbiol. 64: 4973-4982.

HANlon, A. R. M., AND OTHERs. 2006. Dynamics of extracellular polymeric substance (EPS) production and loss in an estuarine, diatom-dominated, microalgal biofilm over a tidal emersion-immersion period. Limnol. Oceanogr. 51: 79-93, doi:10.4319/1o.2006.51.1.0079

Haynes, K., T. A. Hofmann, C. J. Smith, A. S. Ball, G. J. C. Underwood, AND A. M. Osborn. 2007. Diatom-derived carbohydrates as factors affecting bacterial community composition in estuarine sediments. Appl. Environ. Microbiol. 73: 6112-6124, doi:10.1128/AEM.00551-07

Hunter, E. M., H. J. Mills, and J. E. KostKa. 2006. Microbial community diversity associated with carbon and nitrogen cycling in permeable shelf sediments. Appl. Environ. Microbiol. 72: 5689-5701, doi:10.1128/AEM.03007-05

JøRGENSEN, B. B. 2006. Bacteria and marine biogeochemistry, p. 169-206. In H. D. Schulz and M. Zabel [eds.], Marine geochemistry. Springer.

Kerkhof, L., And P. Kemp. 1999. Small ribosomal RNA content in marine Proteobacteria during non-steady-state growth. FEMS Microbiol. Ecol. 30: 253-260, doi:10.1111/j.15746941.1999.tb00653.x

Krumbock, M., AND R. Conrad. 1991. Metabolism of positionlabeled glucose in anoxic methanogenic paddy soil and lake sediment. FEMS Microbiol. Ecol. 85: 247-256, doi:10.1111/ j.1574-6968.1991.tb04731.x

Lewin, J., And J. A. Hellebust. 1976. Heterotrophic nutrition of the marine pennate diatom Nitzschia angularis var. affinis. Mar. Biol. 36: 313-320, doi:10.1007/BF00389192

LoY, A., AND OTHERs. 2002. Oligonucleotide microarray for $16 \mathrm{~S}$ rRNA gene-based detection of all recognized lineages of sulfate-reducing prokaryotes in the environment. Appl. Environ. Microbiol. 68: 5064-5081, doi:10.1128/AEM.68.10. 5064-5081.2002

Ludwig, W., AND OTHERs. 2004. ARB: A software environment for sequence data. Nucl. Acids Res. 32: 1363-1371, doi:10.1093/ nar/gkh293

Macalady, J. L., E. H. Lyon, B. Koffman, L. K. Albertson, K. Meyer, S. Galdenzi, and S. Mariani. 2006. Dominant microbial populations in limestone-corroding stream biofilms, Frasassi cave system, Italy. Appl. Environ. Microbiol. 72: 5596-5609, doi:10.1128/AEM.00715-06

MacGregor, B. J., V. Brüchert, S. Fleischer, and R. Amann. 2002. Isolation of small-subunit rRNA for stable isotopic characterization. Environ. Microbiol. 4: 451-464, doi:10. 1046/j.1462-2920.2002.00324.x

MacIntyre, H. L., R. J. Geider, and D. C. Miller. 1996. Microphytobenthos: The ecological role of the "secret garden" of unvegetated, shallow-water marine habitats. I. Distribution, abundance and primary production. Estuaries 19: 186-201. 
Martinez, R. J., H. J. Mills, S. Story, and P. A. Sobecky. 2006. Prokaryotic diversity and metabolically active microbial populations in sediments from an active mud volcano in the Gulf of Mexico. Environ. Microbiol. 8: 1783-1796, doi:10. 1111/j.1462-2920.2006.01063.x

McKew, B. A., A. J. Dumbrell, J. D. Taylor, T. J. McGenity, AND G. J. C. Underwood. 2013. Differences between aerobic and anaerobic degradation of microphytobenthic biofilmderived organic matter within intertidal sediments. FEMS Microbiol. Ecol. 84: 495-509, doi:10.1111/1574-6941.12077

Middelburg, J. J., C. Barranguet, H. T. S. Boschker, P. M. J. Herman, T. Moens, and C. H. R. Heip. 2000. The fate of intertidal microphytobenthos carbon: An in situ ${ }^{13} \mathrm{C}$-labeling study. Limnol. Oceanogr. 45: 1224-1234, doi:10.4319/ lo.2000.45.6.1224

Mills, H. J., R. J. Martinez, S. Story, and P. A. Sobecky. 2005. Characterization of microbial community structure in Gulf of Mexico gas hydrates: Comparative analysis of DNA- and RNA-derived clone libraries. Appl. Environ. Microbiol. 71: 3235-3247, doi:10.1128/AEM.71.6.3235-3247.2005

Miyajima, T., Y. Yamada, Y. T. Hanba, K. Yoshis, T. Koitabashi, And E. Wada. 1995. Determining the stable isotope ratio of total dissolved inorganic carbon in lakewater by GC/C/IRMS. Limnol. Oceanogr. 40: 994-1000, doi:10. 4319/1o.1995.40.5.0994

Miyatake, T., B. J. MacGregor, and H. T. S. Boschker. 2009. Linking microbial community function to phylogeny of sulfate-reducing Deltaproteobacteria in marine sediments by combining stable isotope probing with magnetic-bead capture hybridization of 16S rRNA. Appl. Environ. Microbiol. 75: 4927-4935, doi:10.1128/AEM.00652-09

2013. Depth-related differences in organic substrate utilization by major microbial groups in intertidal marine sediment. Appl. Environ. Microbiol. 79: 389-392, doi:10.1128/AEM.02027-12

Nogales, B., E. R. B. Moore, W.-R. Abraham, and K. N. Timmis. 1999. Identification of the metabolically active members of a bacterial community in a polychlorinated biphenyl-polluted moorland soil. Environ. Microbiol. 1: 199-212, doi:10.1046/j.1462-2920.1999.00024.x

OAkes, J. M., B. D. Eyre, And J. J. Middelburg. 2012. Transformation and fate of microphytobenthos carbon in subtropical shallow subtidal sands: A ${ }^{13}$ C-labeling study. Limnol. Oceanogr. 57: 1846-1856, doi:10.4319/1o.2012. 57.6.1846

C, - AND H. T. S. BOSCHKER. 2010. Composition, production, and loss of carbohydrates in subtropical shallow subtidal sandy sediments: Rapid processing and long-term retention revealed by ${ }^{13} \mathrm{C}$-labeling. Limnol. Oceanogr. 55: 2126-2138, doi:10.4319/lo.2010.55.5.2126

Paterson, D. M., and K. S. Black. 1999. Water flow, sediment dynamics and benthic biology. Adv. Ecol. Res. 29: 155-193, doi:10.1016/S0065-2504(08)60193-2

Rusch, A., M. Huettel, C. E. Reimers, G. L. Taghon, and C. M. FULLER. 2003. Activity and distribution of bacterial populations in Middle Atlantic Bight shelf sands. FEMS Microbiol. Ecol. 44: 89-100, doi:10.1111/j.1574-6941.2003.tb01093.x

Schönhuber, W., B. Zarda, S. Eix, R. Rippka, M. Herdman, W. Ludwig, AND R. Amann. 1999. In situ identification of cyanobacteria with horseradish peroxidase-labeled, rRNAtargeted oligonucleotide probes. Appl. Environ. Microbiol. 65: $1259-1267$.
Smith, D. J., And G. J. C. Underwood. 1998. Exopolymer production by intertidal epipelic diatoms. Limnol. Oceanogr. 43: 1578-1591, doi:10.4319/1o.1998.43.7.1578

, AND . 2000. The production of extracellular carbohydrates by estuarine benthic diatoms: The effects of growth phase and light and dark treatment. J. Phycol. 36: 321-333, doi:10.1046/j.1529-8817.2000.99148.x

Staats, N., L. J. Stal, B. De Winder, and L. R. Mur. 2000. Oxygenic photosynthesis as driving process in exopolysaccharide production of benthic diatoms. Mar. Ecol. Prog. Ser. 193: 261-269, doi:10.3354/meps 193261

SundH, I. 1992. Biochemical composition of dissolved organic carbon derived from phytoplankton and used by heterotrophic bacteria. Appl. Environ. Microbiol. 58: 2938-2947.

Taylor, J. D., B. A. McKew, A. Kuhl, T. J. McGenity, And G. J. C. Underwood. 2013. Microphytobenthic extracellular polymeric substances (EPS) in intertidal sediments fuel both generalist and specialist EPS-degrading bacteria. Limnol. Oceanogr. 58: 1463-1480.

Underwood, G. J. C., M. Boulcott, C. A. Raines, and K. WALDRON. 2004. Environmental effects on exopolymer production by marine benthic diatoms: Dynamics, changes in composition, and pathways of production. J. Phycol. 40: 293-304, doi:10.1111/j.1529-8817.2004.03076.x

- AND J. KRomKamp. 1999. Primary production by phytoplankton and microphytobenthos in estuaries. Adv. Ecol. Res. 29: 93-153, doi:10.1016/S0065-2504(08)60192-0

- AND D. M. Paterson. 2003. The importance of extracellular carbohydrate production by marine epipelic diatoms. Adv. Bot. Res. 40: 183-240, doi:10.1016/S00652296(05)40005-1

, - AND R. J. Parkes. 1995. The measurement of microbial carbohydrate exopolymers from intertidal sediments. Limnol. Oceanogr. 40: 1243-1253, doi:10.4319/ 10.1995.40.7.1243

— AND D. J. Sмith. 1998. Predicting epipelic diatom exopolymer concentrations in intertidal sediments from sediment chlorophyll $a$. Microb. Ecol. 35: 116-125, doi:10. 1007/s002489900066

van Oevelen, D., J. J. Middelburg, K. Soetaert, and L. Moodley. 2006. The fate of bacterial carbon in an intertidal sediment: Modeling an in situ isotope tracer experiment. Limnol. Oceanogr. 51: 1302-1314, doi:10.4319/lo.2006.51. 3.1302

Veuger, B., D. van Oevelen, H. T. S. Boschker, and J. J. Middelburg. 2006. Fate of peptidoglycan in an intertidal sediment: An in situ ${ }^{13} \mathrm{C}$-labeling study. Limnol. Oceanogr. 51: 1572-1580, doi:10.4319/1o.2006.51.4.1572

Wright, S. W., and S. W. JefFrey. 1987. Fucoxanthin pigment markers of marine-phytoplankton analyzed by HPLC and HPTLC. Mar. Ecol. Prog. Ser. 38: 259-266, doi:10.3354/ meps038259

Associate editor: Bo Thamdrup

Received: 12 July 2013

Accepted: 31 March 2014

Amended: 08 April 2014 